\title{
Differences in Necromass and Carbon and Nitrogen Contents between Node and Internode Material of Dead Bamboo Culms in Two Phyllostachys Species
}

\author{
Shin UGAWA ${ }^{1 *}$, Satoru MIURA and Shinji KANEKO \\ Department of Forest Site Environment, Forestry and Forest Products Research Institute (Tsukuba, \\ Ibaraki 305-8687, Japan)
}

\begin{abstract}
It is necessary to understand the heterogeneity in necromass and carbon (C) and nitrogen (N) contents within a dead bamboo culm before estimating these parameters in dead culms. This study determines differences in necromass and $\mathrm{C}$ and $\mathrm{N}$ contents between node and internode material of decomposing bamboo culms. We collected dead culms of Phyllostachys bambusoides and P. pubescens from 11 bamboo stands in central and south-western Japan, and determined the necromass per culm cylindrical volume (culm volume density), the $\mathrm{C}$ and $\mathrm{N}$ stocks per culm cylindrical volume ( $\mathrm{C}$ and $\mathrm{N}$ densities), and the $\mathrm{C}$ and $\mathrm{N}$ concentrations of node and internode material. In both species the culm volume density was greater in node than internode, which led to a greater $\mathrm{C}$ density in node than internode, whereas the $\mathrm{C}$ concentration scarcely differed between the two. The $\mathrm{N}$ density was greater in node than internode material in both species, due to the difference in culm volume density, while the $\mathrm{N}$ concentration was also greater in node than internode. These differences remained unchanged with the degree of decomposition, because the dynamics of necromass and $\mathrm{C}$ and $\mathrm{N}$ were similar for node and internode materials. The decomposition process in node and internode resembles that in dead wood although variation in $\mathrm{N}$ dynamics is observed for $P$. bambusoides. When the greater culm volume density and $\mathrm{C}$ and $\mathrm{N}$ densities in node than internode were not taken into account, the necromass and $\mathrm{C}$ and $\mathrm{N}$ stocks in a dead bamboo culm decreased by 4.46-4.50, 4.51-4.59 and $9.47-10.83 \%$ respectively. We must sample numerous dead culms to mitigate node and internode differences. However, it might be better to take into account these differences when the number of dead culm samples is limited.
\end{abstract}

Discipline: Forestry and forest products

Additional key words: carbon dynamics, culm volume density, decomposition process, nitrogen dynamics

\section{Introduction}

Bamboo belongs to the subfamily Bambusoideae, containing 90 genera with $>1200$ species that cover approximately $36780 \mathrm{~km}^{2}$ worldwide ${ }^{22}$. The contribution of bamboo forests to carbon $(\mathrm{C})$ and nitrogen $(\mathrm{N})$ cycling cannot be ignored when considering the world carbon budget ${ }^{1,5}$. Accordingly, the parties ratifying the United Nations Framework Convention on Climate Change (UNFCCC) are requested to submit data on $\mathrm{C}$ stock in the bamboo forests of their countries. Additionally, about $80 \%$ of bamboo forests lie within tropical regions of $\mathrm{Asia}^{15}$, which emphasizes the importance of understanding $\mathrm{C}$ and $\mathrm{N}$ cycling in bamboo forests in the context of the recent decline and degradation of tropical forests.

Japan has $1592 \mathrm{~km}^{2}$ of bamboo forests ${ }^{6}$ : Phyllostachys bambusoides Sieb. et Zucc. and P. pubescens Mazel ex Houzeau de Lehaie are grown extensively for the commercial production of edible young shoots ${ }^{11,12,13}$. These species are estimated to cover 36 and $56 \%$ respectively of the total bamboo forest area ${ }^{6}$. The Japanese government is held accountable to the Intergovernmental Panel on Climate Change (IPCC) for $\mathrm{C}$ stocks of the aboveground, belowground, deadwood, litter and soil components in these bamboo forests ${ }^{10}$, for which the regime of $\mathrm{C}$ and $\mathrm{N}$ stocks has been reported for all except the deadwood component ${ }^{12,13,16,24,25,26,28,29,30}$. In bamboo stands, old culms die each

\footnotetext{
Present address:

${ }^{1}$ Faculty of Agriculture, Kagoshima University (Kagoshima, Kagoshima 890-0065, Japan)

*Corresponding author: e-mail ushin@agri.kagoshima-u.ac.jp

Received 24 January 2013; accepted 2 August 2013.
} 
year and new bamboo culms sprout ${ }^{11,31}$. The dead culms remain standing for years, eventually falling and decomposing on the ground and contributing to $\mathrm{C}$ and $\mathrm{N}$ cycling as the deadwood component. However, the structure of bamboo culm tissue differs from that of woody species, featuring a large cavity surrounded by a silica-rich cortex ${ }^{9,21}$ (Fig. $1)$, which indicates the potential for the decomposition process of dead culm to differ from that of dead wood. The decomposition process is unknown for dead bamboo culms. Accordingly, there is a need to understand the decomposition process of dead culm before estimating the quantity of dead bamboo culms (hereinafter referred to as necromass) and their $\mathrm{C}$ and $\mathrm{N}$ stocks.

To estimate the necromass of dead wood in a forest ecosystem, the wood volume is multiplied by the wood density $3,8,18,19,20,23,33$, while the $\mathrm{C}$ and $\mathrm{N}$ stocks are calculated by multiplying the necromass by the $\mathrm{C}$ and $\mathrm{N}$ concentrations in dead wood. This method is applicable to dead bamboo culms if the decomposition process, i.e. $\mathrm{C}$ and $\mathrm{N}$ dynamics, resemble those in dead wood. Ugawa et al. ${ }^{32}$ reported the necromass per culm cylindrical volume (hereinafter referred to as culm volume density), $\mathrm{C}$ and $\mathrm{N}$ stocks per culm cylindrical volume (hereinafter referred to as $\mathrm{C}$ and $\mathrm{N}$ densities), and the $\mathrm{C}$ and $\mathrm{N}$ concentrations for decomposing culm internodes: the changes in these parameters during decomposition resembled those of dead wood. However, the nodes were not accounted for.

Nodes and internodes are found in sequence in a bamboo culm (Fig. 1). The node contains a diaphragm that divides the cavity in the bamboo culm; node tissue has more intensive vascular bundle branching, shorter metaxylem vessels and fiber, and higher ash concentrations than internode material ${ }^{4,21}$, which suggests that the culm volume density and $\mathrm{C}$ and $\mathrm{N}$ contents in nodes differ from those in the internode. Moreover, we should consider the possibility that the differences between node and internode change during decomposition. The morphology of the fibers in a bamboo culm differs between node and internode ${ }^{21}$, and culm fibers with broader layers of polylaminate walls degrade more easily ${ }^{2}$. Accordingly, the decomposition process may differ between node and internode.

In this study we examine differences in culm volume density and $\mathrm{C}$ and $\mathrm{N}$ contents between node and internode. If differences between node and internode are observed, these may be related to the methodology of estimating the necromass and $\mathrm{C}$ and $\mathrm{N}$ stocks in dead culms. The impact of any differences between node and internode on estimates of necromass and $\mathrm{C}$ and $\mathrm{N}$ stocks in the entire bamboo culm were evaluated.

In this study, we aim to: (i) clarify the differences in culm volume density, $\mathrm{C}$ and $\mathrm{N}$ densities, and $\mathrm{C}$ and $\mathrm{N}$ concentrations, between node and internode; (ii) confirm the changes in the differences between node and internode dur-

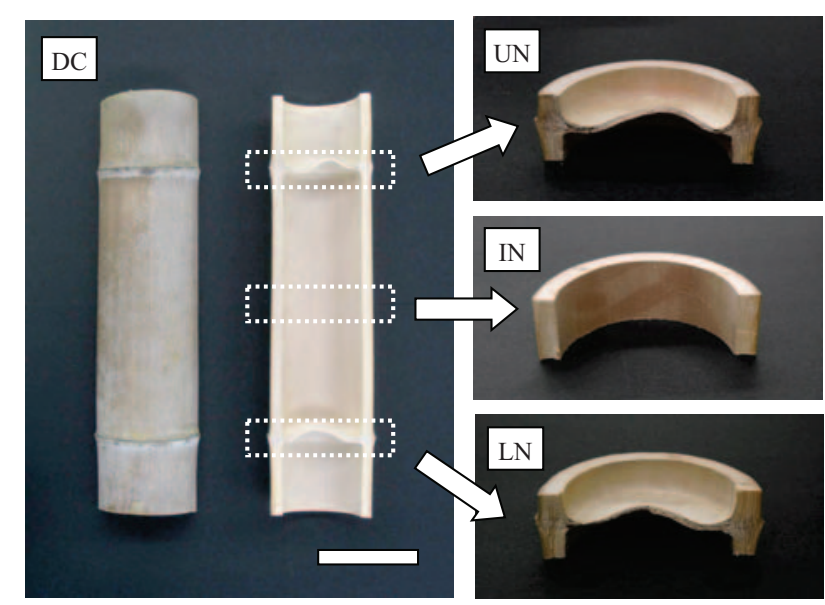

Fig. 1. Upper node (UN), internode (IN) and lower node (LN) of a dead bamboo culm (DC) of Phyllostachys pubescens

The internode is formed by the culm wall surrounding a large cavity. The node contains a diaphragm, which is the plate that divides the cavity in the culm. For the analysis, we used the culm disks indicated by the dotted lines. $\mathrm{Bar}=10 \mathrm{~cm}$.

ing decomposition; and (iii) determine the effect of differences between node and internode on the necromass and $\mathrm{C}$ and $\mathrm{N}$ stock estimates for P. bambusoides and P. pubescens. Accordingly, we measured the culm volume density, $\mathrm{C}$ and $\mathrm{N}$ densities, and $\mathrm{C}$ and $\mathrm{N}$ concentrations of node and internode of dead bamboo culms collected from the bamboo stands of $P$. bambusoides and $P$. pubescens in central and south-western Japan.

\section{Materials and Methods}

\section{Sampling}

We randomly selected three $P$. bambusoides and eight $P$. pubescens stands in warm-temperate zones with high humidity and hot summers, as indicated by Kottek et al. ${ }^{17}$, located in central and south-western Japan where the two species are distributed (Fig. 2 and Table 1). From these stands, we randomly selected standing and fallen dead culms with two neighboring nodes (Fig. 1), and collected 18 dead $P$. bambusoides culms and 50 dead $P$. pubescens culms (Table 2), which were cut and transported to the laboratory.

\section{Measurement and calculation of parameters}

A dead bamboo culm might undergo trends involving consistent increases in culm volume density and $\mathrm{N}$ content from the bottom to the top of the culm ${ }^{7,27}$. There is therefore a need to compare the parameters of two adjacent nodes with the internode material between them. The distance between two neighboring nodes, i.e. internode length, was measured and the culms were cut transversely into $3-\mathrm{cm}$ length disks in three positions (Fig. 1: lower node, middle- 


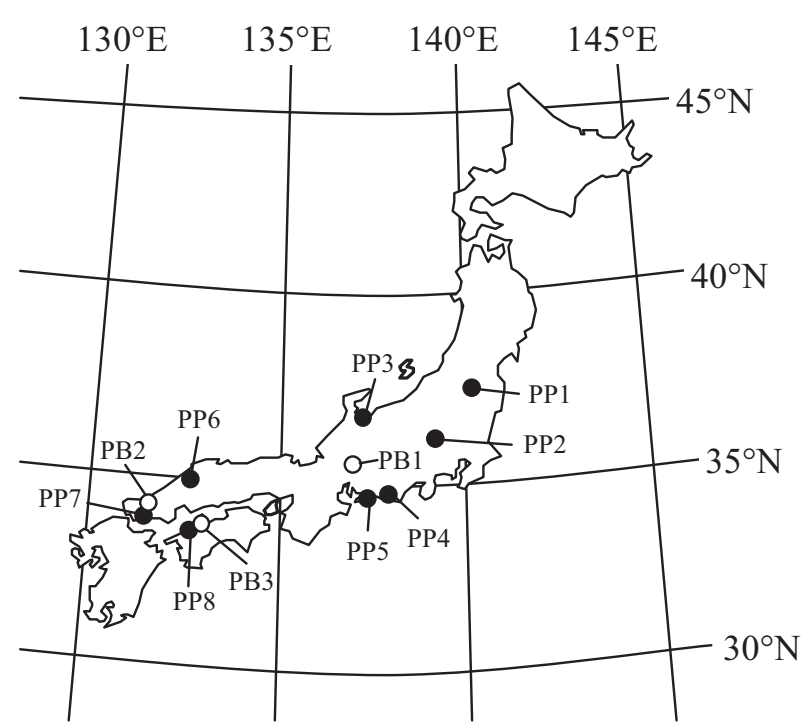

Fig. 2. Locations of sampling stands

Samples of Phyllostachys bambusoides were taken from three stands (open circle) and P. pubescens from eight stands (solid circle).

position internode, and upper node).

The diameters of all the culm disks were measured, and the wall thicknesses of the internode disks were determined. The culm disks were then oven-dried at $70^{\circ} \mathrm{C}$ for 48 $\mathrm{h}$ and weighed. The dried culm disks were finely ground using a cutting mill and an agate mortar, and the $\mathrm{C}$ and $\mathrm{N}$ concentrations were measured using dry combustion methods with an NC analyzer (vario MAX CN; Elementar Analysensysteme GmbH, Hanau, Germany).

We calculated the cylindrical volume of the culm disk using Formula 1 below, where variables $\mathrm{D}$ and $\mathrm{L}$ denote the culm disk diameter and length $(=3 \mathrm{~cm})$. For the internode, the wall volume of culm disks was calculated using Formula 2 below, where variables $\mathrm{D}, \mathrm{L}$, and $\mathrm{T}$ denote the culm disk diameter, length $(=3 \mathrm{~cm})$ and wall thickness. The culm volume density was determined by dividing the culm disk weight by its cylindrical volume. The wall density of the internode disk was determined by dividing the culm disk weight by the wall volume. We calculated the $\mathrm{C}$ and $\mathrm{N}$ densities of the culm disk by multiplying the culm volume density by the $\mathrm{C}$ and $\mathrm{N}$ concentrations.

[Formula 1] Culm cylindrical volume $=\pi\left(\frac{\mathrm{D}}{2}\right)^{2} \mathrm{~L}$

[Formula 2] Wall volume $=\pi\left(\frac{\mathrm{D}}{2}\right)^{2} \mathrm{~L}-\pi\left(\frac{\mathrm{D}}{2}-\mathrm{T}\right)^{2} \mathrm{~L}$

\section{Statistical analysis}

Statistical analyses were conducted for each of the two bamboo species.

To examine differences in the culm volume density, $\mathrm{C}$ and $\mathrm{N}$ densities, and $\mathrm{C}$ and $\mathrm{N}$ concentrations between node and internode, the five parameters were each compared between pairs of culm disk positions (i.e. lower node, internode, and upper node) using Tukey's HSD test.

To confirm changes in how the five parameters differed between node and internode during decomposition, we calculated the lower and upper node-to-internode ratios of each parameter, to represent the difference between node and internode. We then analyzed the change in the lower and upper node-to-internode ratios against the wall density of internode, using a generalized linear mixed model with Gaussian error (Formula 3). Here, the wall density of the internode was used to indicate the degree of decomposition, because a decrease in wall density implies the loss of necromass during decomposition ${ }^{32}$, analogous to dead wood of tree species $3,8,18,19,20,23,33$. A wall density of decomposing

Table 1. Community characteristics of each sampled stand of Phyllostachys bambusoides and P. pubescens

\begin{tabular}{lccccccc}
\hline \hline Species & Stand & $\begin{array}{c}\text { Slope } \\
\text { direction }\end{array}$ & $\begin{array}{c}\text { Inclination } \\
\left({ }^{\circ}\right)\end{array}$ & $\begin{array}{c}\text { Culm } \\
\text { density } \\
\left(\mathrm{N} \mathrm{ha}^{-1}\right)\end{array}$ & $\begin{array}{c}\text { DBH } \\
(\mathrm{cm})\end{array}$ & $\begin{array}{c}\text { Mean } \\
\text { temperature }{ }^{* 2} \\
\left({ }^{\circ} \mathrm{C}\right)\end{array}$ & $\begin{array}{c}\text { Precipitation }^{* 2} \\
\left(\mathrm{~mm}^{*} \text { year }^{-1}\right)\end{array}$ \\
\hline P. bambusoides & PB1 & NE & 2 & 15200 & $4.3 \pm 1.6$ & 14.0 & 2205 \\
& PB2 & W & 35 & 7200 & $7.3 \pm 2.2$ & 12.1 & 2252 \\
& PB3 & E & 29 & 6900 & $7.2 \pm 2.4$ & 12.9 & 1794 \\
\hline P. pubescens & PP1 & SE & 22 & 5500 & $7.0 \pm 1.3$ & 10.8 & 1328 \\
& PP2 & N & 3 & 5300 & $6.9 \pm 1.7$ & 13.5 & 1133 \\
& PP3 & N & 3 & 8100 & $8.9 \pm 2.1$ & 13.2 & 2232 \\
& PP4 & N & 36 & 5500 & $11.8 \pm 2.0$ & 15.2 & 1784 \\
& PP5 & S & 28 & 9400 & $9.8 \pm 1.9$ & 15.0 & 1745 \\
& PP6 & N & 32 & 4900 & $10.5 \pm 1.7$ & 11.2 & 1972 \\
& PP7 & E & 27 & 6200 & $9.1 \pm 1.9$ & 14.6 & 1721 \\
& PP8 & W & 27 & 9200 & $11.8 \pm 2.1$ & 12.9 & 1794 \\
\hline
\end{tabular}

${ }^{* 1}$ Mean \pm sample standard deviation of the diameter at breast height for living bamboo culms.

${ }^{* 2}$ Mean value in 1971-2000 (Japan Meteorological Agency ${ }^{14}$ ). 
Table 2. Number and three characteristics (mean \pm sample standard deviation) of dead culms sampled from each bamboo stand of Phyllostachys bambusoides and P. pubescens

\begin{tabular}{|c|c|c|c|c|c|}
\hline Species & Stand & $\begin{array}{l}\text { Number } \\
\text { of } \\
\text { samples }\end{array}$ & $\begin{array}{l}\text { Internode length }{ }^{* 1} \\
(\mathrm{~cm})\end{array}$ & $\begin{array}{l}\text { Culm diameter }{ }^{* 2} \\
(\mathrm{~cm})\end{array}$ & $\begin{array}{l}\text { Wall density }{ }^{* 3} \\
\quad\left(\mathrm{mg} \mathrm{cm}^{-3}\right)\end{array}$ \\
\hline \multirow[t]{4}{*}{ P. bambusoides } & PB1 & 7 & $26.1 \pm 8.6$ & $4.7 \pm 1.0$ & $578 \pm 64$ \\
\hline & PB2 & 4 & $25.3 \pm 3.1$ & $5.7 \pm 1.6$ & $591 \pm 49$ \\
\hline & PB3 & 7 & $30.7 \pm 5.8$ & $5.8 \pm 1.6$ & $564 \pm 142$ \\
\hline & Total & 18 & $27.7 \pm 6.8$ & $5.4 \pm 1.4$ & $576 \pm 96$ \\
\hline \multirow[t]{9}{*}{ P.pubescens } & PP1 & 4 & $14.5 \pm 3.4$ & $5.8 \pm 1.0$ & $431 \pm 183$ \\
\hline & PP2 & 5 & $18.8 \pm 6.7$ & $6.7 \pm 1.7$ & $515 \pm 87$ \\
\hline & PP3 & 7 & $21.2 \pm 7.0$ & $6.0 \pm 1.1$ & $542 \pm 107$ \\
\hline & PP4 & 3 & $24.7 \pm 3.7$ & $8.5 \pm 2.9$ & $506 \pm 102$ \\
\hline & PP5 & 8 & $17.1 \pm 5.2$ & $8.3 \pm 1.8$ & $529 \pm 114$ \\
\hline & PP6 & 5 & $27.6 \pm 9.6$ & $6.1 \pm 1.5$ & $681 \pm 92$ \\
\hline & PP7 & 6 & $17.5 \pm 4.3$ & $9.3 \pm 2.1$ & $555 \pm 64$ \\
\hline & PP8 & 12 & $21.2 \pm 4.9$ & $9.6 \pm 1.9$ & $491 \pm 107$ \\
\hline & Total & 50 & $20.2 \pm 6.5$ & $7.8 \pm 2.2$ & $527 \pm 117$ \\
\hline
\end{tabular}

internodes might indicate a varying degree of decomposition among sampling stands because the initial wall density of internodes may differ among sampling stands. We therefore focused on detecting comprehensive changes in the node-to-internode ratios: the sampling stand was considered as both a random intercept and a random slope in distinguishing the variation among sampling stands. To further clarify the change in the five parameters during decomposition, we analyzed the change in each parameter for the internode, and lower and upper nodes versus the wall density of internode using a generalized linear mixed model with Gaussian error (Formula 4). The sampling stand was considered as both a random intercept and a random slope in distinguishing the variation among sampling stands.

[Formula 3] Lower and upper node-to-internode ratios $=$ Wall density of internode $+($ Stand $)+($ Stand $\mid$ Wall density of internode)

[Formula 4] Parameter of internode, lower and upper nodes $=$ Wall density of internode $+($ Stand $)+($ Stand $\mid$ Wall density of internode)

Finally, to determine the effect of the differences in the five parameters between node and internode on necromass and $\mathrm{C}$ and $\mathrm{N}$ stock estimates, we calculated the necromass and $\mathrm{C}$ and $\mathrm{N}$ stocks of a 3-cm-length disk for the internodes (hereinafter referred to as the internode value). We also calculated the intermediate value (hereinafter referred to as the node value) in necromass and $\mathrm{C}$ and $\mathrm{N}$ stocks between the lower and upper nodes of 3-cm-length disks in each dead culm. Next, we calculated the necromass and $\mathrm{C}$ and $\mathrm{N}$ stocks in each dead culm using Formulas 5 and 6 (below), where the internode length is specified in centimeters. In Formula 5, we assumed a bamboo culm containing a node within an internode length. In Formula 6, we assumed a bamboo culm consisting solely of an internode. We then determined the mean value of the necromass and $\mathrm{C}$ and $\mathrm{N}$ stocks in dead culms with and without a node.

[Formula 5] Parameter of a bamboo culm with a node $=$

$$
\text { Node value }+\left(\frac{\text { Internode value }}{3}\right) \times(\text { Internode length }-3)
$$

[Formula 6] Parameter of a dead culm without a node $=$

$$
\left(\frac{\text { Internode value }}{3}\right) \times \text { Internode length }
$$

All statistical analyses were performed using JMP 5.1 (SAS Institute, Cary, NC, USA).

\section{Results and discussion}

\section{Differences in necromass and $\mathrm{C}$ and $\mathrm{N}$ contents between node and internode}

The culm volume density was greater in node than internode (Table 3; for P. bambusoides, $p<0.001$ in the lower node and $p<0.001$ in the upper node; for $P$. pubescens, $p<0.001$ in the lower node and $p<0.001$ in the upper 
Table 3. Culm volume density, carbon (C) and nitrogen ( $N$ ) densities, and $\mathrm{C}$ and $\mathrm{N}$ concentrations (mean \pm sample standard error) in lower and upper nodes and internodes of dead culms of Phyllostachys bambusoides and P. pubescens

\begin{tabular}{|c|c|c|c|c|c|}
\hline Species & Parameter & $\begin{array}{c}\text { Number } \\
\text { of } \\
\text { samples }\end{array}$ & Lower node & Internode & Upper node \\
\hline \multirow[t]{5}{*}{ P. bambusoides } & Culm volume density $\left(\mathrm{mg} \mathrm{cm}^{-3}\right)$ & 18 & $308 \pm 21^{a}$ & $227 \pm 16^{b}$ & $293 \pm 19^{a}$ \\
\hline & $\mathrm{C}$ density $\left(\mathrm{mg} \mathrm{cm}^{-3}\right)$ & 18 & $154 \pm 10^{a}$ & $113 \pm 8^{b}$ & $146 \pm 10^{a}$ \\
\hline & $\mathrm{N}$ density $\left(\mathrm{mg} \mathrm{cm}^{-3}\right)$ & 18 & $0.42 \pm 0.03^{\mathrm{a}}$ & $0.21 \pm 0.02^{b}$ & $0.40 \pm 0.03^{\mathrm{a}}$ \\
\hline & $\mathrm{C}$ concentration $\left(\mathrm{g} \mathrm{kg}^{-1}\right)$ & 18 & $499 \pm 1^{\text {a }}$ & $497 \pm 1^{b}$ & $499 \pm 1^{\text {a }}$ \\
\hline & $\mathrm{N}$ concentration $\left(\mathrm{g} \mathrm{kg}^{-1}\right)$ & 18 & $1.49 \pm 0.18^{\mathrm{a}}$ & $1.00 \pm 0.12^{b}$ & $1.48 \pm 0.18^{\mathrm{a}}$ \\
\hline \multirow[t]{5}{*}{ P.pubescens } & Culm volume density $\left(\mathrm{mg} \mathrm{cm}^{-3}\right)$ & 50 & $269 \pm 9^{a}$ & $208 \pm 6^{\mathrm{b}}$ & $265 \pm 9^{a}$ \\
\hline & $\mathrm{C}$ density $\left(\mathrm{mg} \mathrm{cm}^{-3}\right)$ & 50 & $135 \pm 4^{\mathrm{a}}$ & $104 \pm 3^{b}$ & $132 \pm 4^{\mathrm{a}}$ \\
\hline & $\mathrm{N}$ density $\left(\mathrm{mg} \mathrm{cm}^{-3}\right)$ & 50 & $0.65 \pm 0.04^{\mathrm{a}}$ & $0.41 \pm 0.02^{\mathrm{b}}$ & $0.70 \pm 0.04^{\mathrm{a}}$ \\
\hline & $\mathrm{C}$ concentration $\left(\mathrm{g} \mathrm{kg}^{-1}\right)$ & 50 & $500 \pm 0^{\mathrm{a}}$ & $500 \pm 0^{a}$ & $500 \pm 0^{\mathrm{a}}$ \\
\hline & $\mathrm{N}$ concentration $\left(\mathrm{g} \mathrm{kg}^{-1}\right)$ & 50 & $2.60 \pm 0.22^{\mathrm{a}}$ & $2.14 \pm 0.19^{b}$ & $2.80 \pm 0.22^{\mathrm{c}}$ \\
\hline
\end{tabular}

These values were calculated using a generalized linear mixed model in which the sampling stand was incorporated as a random effect; the model formula was $[$ Parameter $=($ Stand $)]$. Different letters indicate a significant difference between culm disk positions (Tukey's HSD test: $\mathrm{p} \leq 0.050$ )

node). This might be due to the diaphragm.

The $\mathrm{C}$ density was also greater in node than internode (Table 3; for P. bambusoides, $p<0.001$ in the lower node and $p<0.001$ in the upper node; for P. pubescens, $p<0.001$ in the lower node and $p<0.001$ in the upper node). The $\mathrm{C}$ density is calculated from the necromass and $\mathrm{C}$ concentration. In $P$. pubescens, the $\mathrm{C}$ concentration did not differ between node and internode $(p=0.161$ in the lower node and $p=0.079$ in the upper node). In P. bambusoides, the $\mathrm{C}$ concentration was greater in node than internode $(p<0.001$ in the lower node and $p<0.001$ in the upper node), but the mean difference between node and internode (i.e. $1.9 \mathrm{~g} \mathrm{~kg}^{-1}$ ) was very small relative to the mean $\mathrm{C}$ concentration of about $500 \mathrm{~g} \mathrm{~kg}^{-1}$. These results indicate that the $\mathrm{C}$ concentration has little influence on the difference in $\mathrm{C}$ density between node and internode, meaning the difference in $\mathrm{C}$ density between node and internode is due to the difference in culm volume density.

The $\mathrm{N}$ density was greater in node than internode (Table 3; for P. bambusoides, $p<0.001$ in the lower node and $p<0.001$ in the upper node; for P. pubescens, $p<0.001$ in the lower node and $p<0.001$ in the upper node). The $\mathrm{N}$ density is calculated from the necromass and $\mathrm{N}$ concentration. Interestingly, the $\mathrm{N}$ concentration was greater in node than internode (Table 3; for P. bambusoides, $p<0.001$ in the lower node and $p<0.001$ in the upper node; for $P$. pubescens, $p<0.001$ in the lower node and $p<0.001$ in the upper node). Thus, the difference in $\mathrm{N}$ density between node and internode is likely to be due to the difference in $\mathrm{N}$ concentrations as well as in culm volume density. The high $\mathrm{N}$ concentration corresponds to high ash concentrations in nodes of living culm, and may be related to physiological function, e.g. intensive vascular bundle branching ${ }^{21}$.

\section{Differences in necromass and $\mathbf{C}$ and $\mathbf{N}$ dynamics between node and internode}

The node-to-internode ratio of the culm volume density remained unchanged with the wall density of the internode material, the indicator of the degree of decomposition (Fig. 3; for P. bambusoides, $p=0.824$ in the lower node and $p=0.748$ in the upper node; for $P$. pubescens, $p=0.946$ in the lower node and $p=0.958$ in the upper node). The culm volume density of the node and internode decreased with the degree of decomposition, although the $p$-value was not significant for the lower node of $P$. bambusoides, and was close to 0.050 (Fig. 4; for P. bambusoides, $p=0.053$ in the lower node, $p=0.025$ in the internode and $p=0.045$ in the upper node; for $P$. pubescens, $p<0.001$ in the lower node, $p$ $<0.001$ in the internode and $p<0.001$ in the upper node). We therefore suggest that the decrease in necromass during decomposition is common between node and internode, so that the difference in culm volume density between node and internode is maintained. In dead wood, the difference in decomposition rates between heartwood and sapwood is explained by the difference in lignin and other antimicrobial extractives (e.g. polyphenols, terpenoids and tannins) rather than any difference in tissue or cell structures ${ }^{34}$. Thus, the differences in tissues and cell structures between node and internode ${ }^{4,21}$ may not influence their decomposition rates.

The $\mathrm{C}$ density node-to-internode ratio remained unchanged with the degree of decomposition (Fig. 3; for $P$. bambusoides, $p=0.825$ in the lower node and $p=0.747$ in the upper node; for $P$. pubescens, $p=0.946$ in the lower node and $p=0.993$ in the upper node). The $\mathrm{C}$ density of 


\section{P. bambusoides}

Lower node

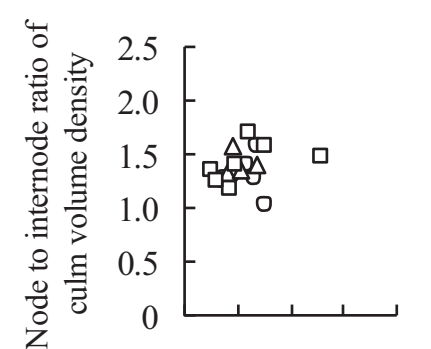

Upper node
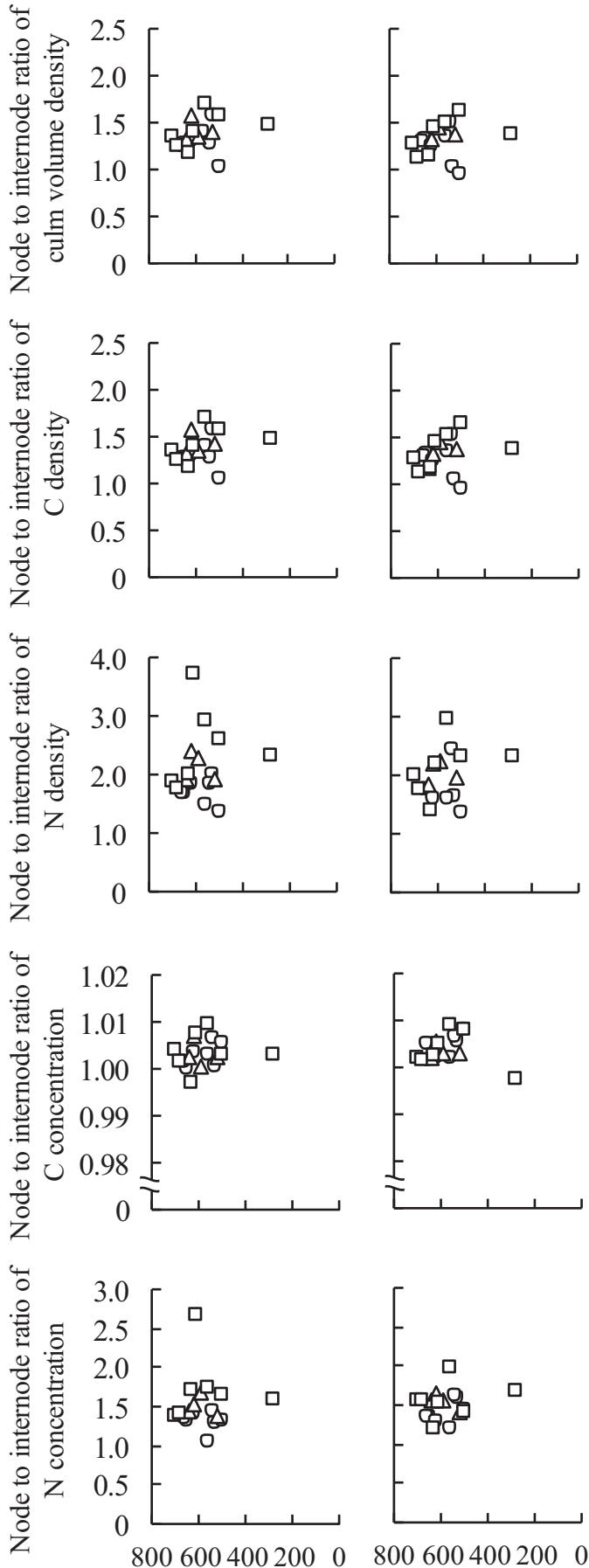

P. pubescens

Lower node

Upper node

\begin{tabular}{|l|}
\hline O PB1 \\
$\triangle$ PB2 \\
$\square$ PB3 \\
\hline
\end{tabular}
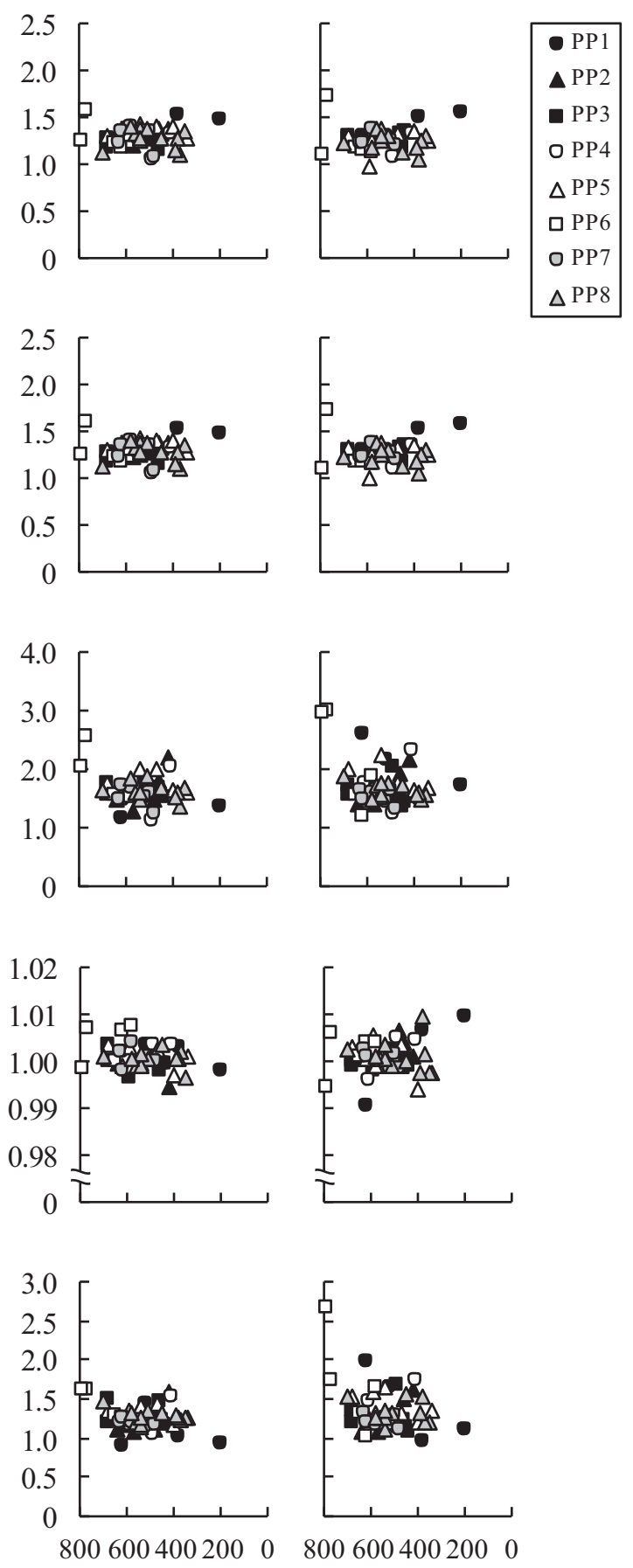

Wall density of internode $\left(\mathrm{mg} \mathrm{cm}^{-3}\right)$

Fig. 3. Changes in lower and upper node-to-internode ratios of the culm volume density, carbon (C) and nitrogen (N) densities, and $\mathrm{C}$ and $\mathrm{N}$ concentrations versus the wall density of internode of dead culms in each bamboo stand of Phyllostachys bambusoides and P. pubescens

The wall density of internode material was used to indicate the degree of decomposition, and is shown on the $\mathrm{x}$ axis in the reverse direction. 
P. bambusoides

$$
\text { ?ే }
$$
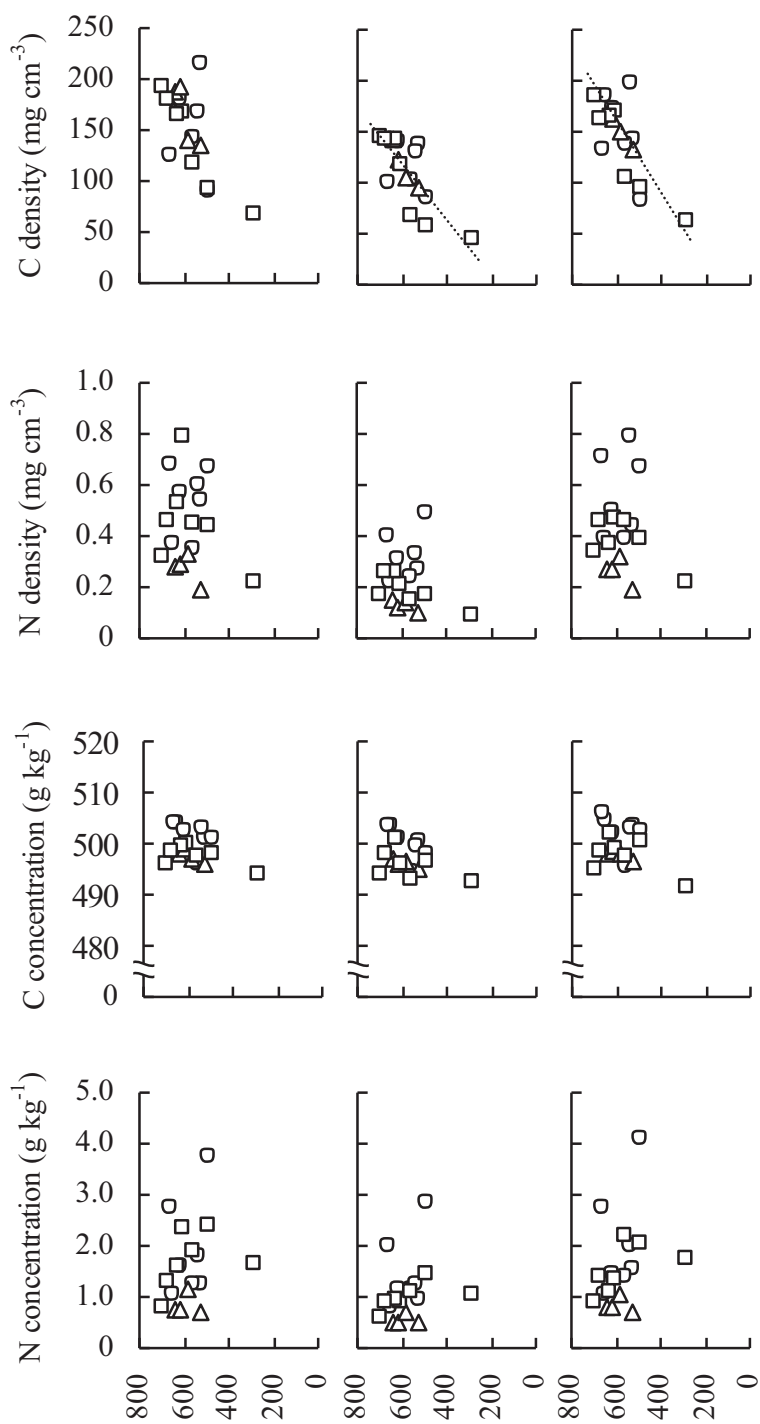

P. pubescens
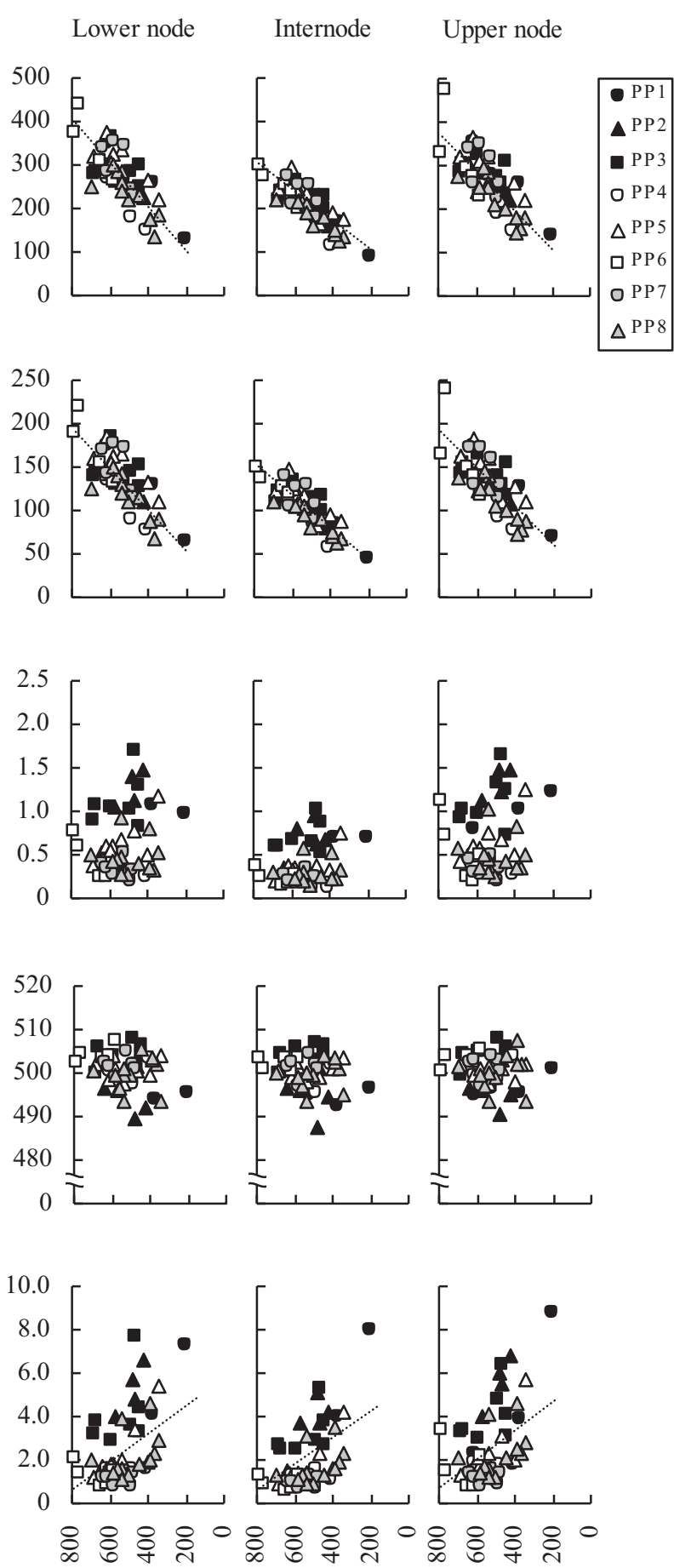

Wall density of internode $\left(\mathrm{mg} \mathrm{cm}^{-3}\right)$

Fig. 4. Changes in culm volume density, carbon (C) and nitrogen $(\mathrm{N})$ densities, and $\mathrm{C}$ and $\mathrm{N}$ concentrations of internode, lower and upper nodes versus the wall density of internode material of dead culms in each bamboo stand of Phyllostachys bambusoides and $P$. pubescens

The wall density of internode material was used to indicate the degree of decomposition, and is shown on the $\mathrm{x}$ axis in the reverse direction. The dotted line is a significant regression line $(p<0.050)$, estimated using a generalized linear mixed model. 
Table 4. Necromass and carbon (C) and nitrogen (N) stocks (mean \pm sample standard error) in dead culms with and without a node, and their relative differences for dead culms of Phyllostachys bambusoides and $P$. pubescens

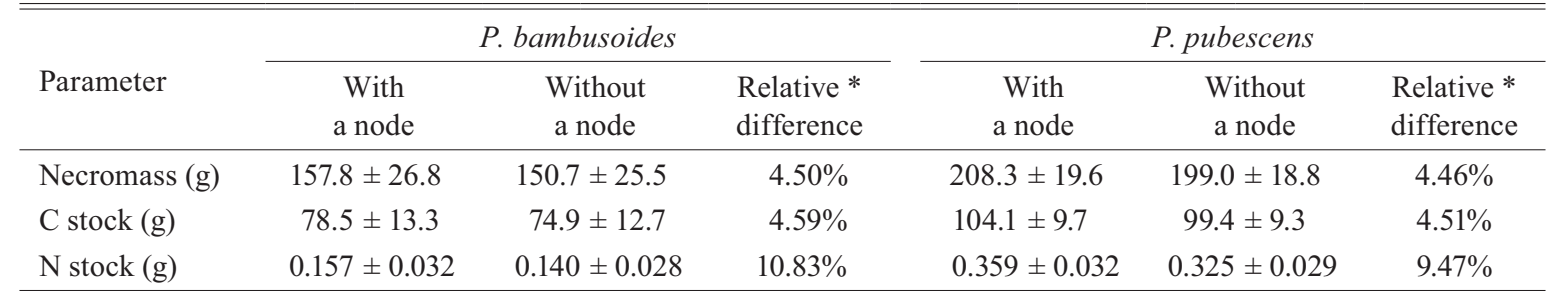

The necromass and $\mathrm{C}$ and $\mathrm{N}$ stocks were calculated using a generalized linear mixed model in which the sampling stand was incorporated as a random effect; the model formula was [Parameter $=($ Stand $)]$.

${ }^{*}$ Percentage difference in the mean values of each parameter of dead culms with and without a node relative to the mean value of the parameter of dead culms with a node.

node and internode decreased with the degree of decomposition, although the $p$-value was not significant for the lower node of $P$. bambusoides, and was close to 0.050 (Fig. 4; for $P$. bambusoides: $p=0.051$ in the lower node, $p=0.043$ in the internode and $p=0.025$ in the upper node; for $P$. pubescens, $\mathrm{p}<0.001$ in the lower node, $p<0.001$ in the internode and $p<0.001$ in the upper node). We therefore suggest that the decrease in $\mathrm{C}$ density during decomposition is similar for both node and internode, so that the difference in $\mathrm{C}$ density between node and internode is maintained. The $\mathrm{C}$ concentration of node and internode remained unchanged with the degree of decomposition (for $P$. bambusoides, $p=0.087$ in the lower node, $p=0.120$ in the internode and $p=0.260$ in the upper node; for P. pubescens, $p=0.653$ in the lower node, $p=0.693$ in the internode and $p=0.207$ in the upper node), which indicates that the decrease in $\mathrm{C}$ density is explained by the loss of necromass, which mainly comprises carbon. Thus, the common $\mathrm{C}$ dynamics of node and internode appear to derive from the common dynamics of their necromass.

The $\mathrm{N}$ density node-to-internode ratio remained unchanged with the degree of decomposition (Fig. 3; for $P$. bambusoides, $p=0.891$ in the lower node and $p=0.838$ in the upper node; for $P$. pubescens, $p=0.760$ in the lower node and $p=0.084$ in the upper node). The $\mathrm{N}$ density remained unchanged with the degree of decomposition in either node and internode (Fig. 4; for P. bambusoides, $p=$ 0.601 in the lower node, $p=0.814$ in the internode and $p=$ 0.722 in the upper node; for $P$. pubescens, $p=0.101$ in the lower node, $p=0.161$ in the internode and $p=0.339$ in the upper node). The common tendency for the $\mathrm{N}$ density to remain unchanged during decomposition should maintain the difference in $\mathrm{N}$ density between node and internode. However, the absence of any change in $\mathrm{N}$ density appears to have different causes in the two bamboo species. In $P$. pubescens, the $\mathrm{N}$ concentration increased with the degree of decomposition ( $p<0.001$ in the lower node, $p<0.001$ in the internode and $p<0.001$ in the upper node), which is due to the loss of necromass, because the amount of $\mathrm{N}$ (i.e. $\mathrm{N}$ density) remained unchanged during decomposition. The lack of change in $\mathrm{N}$ density may result from the immobilization of $\mathrm{N}^{18,19,23}$. In $P$. bambusoides, the $\mathrm{N}$ concentration did not increase ( $p=0.593$ in the lower node, $p=0.491$ in the internode and $p=0.423$ in the upper node) regardless of the decrease in culm volume density, although no change in $\mathrm{N}$ density during decomposition was detected. The lack of change in $\mathrm{N}$ density may therefore be attributable to the high variation in $\mathrm{N}$ dynamics.

\section{Influence of differences in necromass and $\mathrm{C}$ and $\mathrm{N}$ contents on estimates of $\mathbf{C}$ and $\mathbf{N}$ stocks}

Table 4 shows estimates of the necromass and $\mathrm{C}$ and $\mathrm{N}$ stocks in dead culms with and without taking into account the difference between node and internode. When the greater culm volume density in node than internode was not taken into account, the necromass was decreased by $4.50 \%$ in P. bambusoides and $4.46 \%$ in P. pubescens. Similarly, the $\mathrm{C}$ stock was decreased by $4.59 \%$ in $P$. bambusoides and $4.51 \%$ in $P$. pubescens. In the case of $\mathrm{N}$ stocks, the decrease was $10.83 \%$ in P. bambusoides and $9.47 \%$ in P. pubescens.

In actual surveys, we collect dead culm samples containing nodes randomly, which means the effect of differences between node and internode on estimates of necromass and $\mathrm{C}$ and $\mathrm{N}$ stocks is smaller than the percentages described above. The differences between node and internode need not be considered when estimating the necromass and $\mathrm{C}$ and $\mathrm{N}$ stocks in dead culms when numerous dead culms are sampled. Conversely, it might be better to take into account the differences between node and internode when the number of dead culm samples is limited due to the cost and time of field survey.

\section{Conclusion}

We have confirmed in this study the greater values in culm volume density, in $\mathrm{C}$ and $\mathrm{N}$ densities, and in $\mathrm{N}$ con- 
centration in nodes than in internode material for two Phyllostachys species. However, these differences remained unchanged during decomposition, indicating homogeneity in the decomposition process between node and internode. The decomposition process in node and internode resembles that in dead wood although variation in $\mathrm{N}$ dynamics is observed for $P$. bambusoides. This means that the method of estimating $\mathrm{C}$ and $\mathrm{N}$ stocks of dead wood is also applicable to dead culms. The necromass and $\mathrm{C}$ and $\mathrm{N}$ stocks in dead bamboo culms are decreased by 4.46-4.50, 4.51-4.59 and $9.47-10.83 \%$ respectively when the node is not taken into account. The effect of differences between node and internode will be reduced when numerous dead culms are sampled. However, the differences between node and internode must be taken into account when the number of dead culm samples is limited. Bamboo forests are widely distributed worldwide, especially in tropical regions. It is important to recognize the differences between node and internode to estimate $\mathrm{C}$ and $\mathrm{N}$ stocks in these bamboo forests more accurately.

\section{Acknowledgements}

We are grateful to the researchers at the prefectural forest research institutes for collecting dead culm samples. We would also like to thank M. Takahashi (Department of Forest Site Environment, Forestry and Forest Products Research Institute) and Y. Kiyono and M. Takeuchi (Bureau of Climate Change, Forestry and Forest Products Research Institute) for arranging the sampling processes. Thanks also to Y. Itakura (Department of Wood Processing, Forestry and Forest Products Research Institute) and H. Takahashi, A. Tagawa, M. Nemoto, and Y. Katsui (Department of Forest Site Environment, Forestry and Forest Products Research Institute) for analyzing the dead culm samples. This study was supported by the National Forest Soil Carbon Inventory, managed by the Forestry Agency of Japan.

\section{References}

1. Chen, X.G. et al. (2009) Changes of carbon stocks in bamboo stands in China during 100 years. For. Ecol. Manage., 258, 1489-1496.

2. Cho, C.H. et al. (2008) Micromorphological characteristics of bamboo (Phyllostachys pubescens) fibers degraded by brown rot fungus (Gloeophyllum trabeum). J. Wood Sci., 54, 261-265.

3. Currie, W.S. \& Nadelhoffer, K.J. (2002) The imprint of landuse history: patterns of carbon and nitrogen in downed woody debris at the Harvard Forest. Ecosystems, 5, 446-460.

4. Ding, Y. \& Liese W. (1995) On the nodal structure of bamboo. J. Bamboo Res., 14, 24-32 [In Chinese with English summary].

5. Du, H. et al. (2010) Spatial heterogeneity and carbon contribution of aboveground biomass of moso bamboo by using geostatistical theory. Plant Ecol., 207, 131-139.

6. Forestry Agency (2007) Implementation report of the National Forest Carbon Inventory in FY2007. Forest Agency, Tokyo, Japan [In Japanese].

7. Hamdan, H. et al. (2009) Mechanical properties and failure behaviour of Gigantochloa scortechinii. J. Trop. For. Sci., 21, 336-344.

8. Harmon, M.E. et al. (1986) Ecology of coarse woody debris in temperate ecosystems. Adv. Ecol. Res., 15, 133-302.

9. Imai, T. et al. (1995) Cellular structures in culm internodes of three Phyllostachys species, Madake, Hachiku and Mosochiku (1). Bull. Kyoto Univ. For., 65, 147-157 [In Japanese with English summary].

10. IPCC (2006) 2006 IPCC Guidelines for National Greenhouse Gas Inventories. Institute for Global Environmental Strategies, Hayama, Japan.

11. Isagi, Y. et al. (1993) Biomass and net production in a bamboo Phyllostachys bambusoides stand. Ecol. Res., 8, 123133.

12. Isagi, Y. (1994) Carbon stock and cycling in a bamboo Phyllostachys bambusoides stand. Ecol. Res., 9, 47-55.

13. Isagi, Y. et al. (1997) Net production and carbon cycling in a bamboo Phyllostachys pubescens stand. Plant Ecol., 130, 4152.

14. Japan Meteorological Agency (2002) Mesh climatic data 2000. Japan Meteorological Agency, Tokyo, Japan [In Japanese].

15. Kigomo, B.N. (1988) Distribution, cultivation and research status of bamboo in eastern Africa, Ecological Series Monograph 1, Kenya Forest Research Institute, Nairobi, Kenya, pp. 47.

16. Kiyono, Y. et al. (2007) Predicting chronosequential changes in carbon stocks of pachymorph communities in slash-andburn agricultural fallow, northern Lao People's Democratic Republic. J. For. Res., 12, 371-383.

17. Kottek, M. et al. (2006) World map of the Köppen-Geiger climate classification, updated. Meteorol. Z., 15, 259-263.

18. Laiho, R. \& Prescott, C.E. (1999) The contribution of coarse woody debris to carbon, nitrogen, and phosphorus cycles in three Rocky Mountain coniferous forests. Can. J. For. Res., 29, 1592-1603.

19. Laiho, R. \& Prescott, C.E. (2004) Decay and nutrient dynamics of coarse woody debris in northern coniferous forests: a synthesis. Can. J. For. Res., 34, 763-777.

20. Lambert, R.L. et al. (1980) Loss of mass and chemical change in decaying boles of a subalpine balsam fir forest. Ecology, 61, 1460-1473.

21. Liese, W. (1998) The anatomy of bamboo culms. International Network for Bamboo and Rattan, Beijing, China, pp. 204.

22. Lobovikov, M. et al. (2007) World bamboo resources. A thematic study prepared in the framework of the Global Forest Resources Assessment 2005. Food and Agriculture Organization of the United Nations, Rome, Italy, pp. 73.

23. Palviainen, M. et al. (2010) Carbon and nitrogen release from decomposing Scots pine, Norway spruce and silver birch stumps. For. Ecol. Manage., 259, 390-398.

24. Shanmughavel, P. \& Francis, K. (1996) Biomass and nutrient cycling in bamboo (Bambusa bambos) plantations of tropical areas. Biol. Fertil. Soils, 23, 431-434.

25. Shanmughavel, P. \& Francis, K. (1997) Balance and turnover of nutrients in a bamboo plantation (Bambusa bambos) of different ages. Biol. Fertil. Soils, 25, 69-74. 
26. Shanmughavel, P. \& Francis, K. (2001) Bioproductivity and nutrient cycling in bamboo and acacia plantation forest. Bioresource Technol., 80, 45-48.

27. Shibamoto, T. et al. (1955) Studies on some properties of stem and shoot of bamboo (Phyllostachys edulis Riv.). (No. 3) On nitrogenous matters in shoot of bamboo. Bull. Tokyo Univ. For., 48, 209-220 [In Japanese with English summary].

28. Singh, A.N. \& Singh, J.S. (1999) Biomass, net primary production and impact of bamboo plantation on soil redevelopment in a dry tropical region. For. Ecol. Manage., 119, 195-207.

29. Tripathi, S.K. \& Singh, K.P. (1992) Nutrient immobilization and release patterns during plant decomposition in a dry tropical bamboo savanna, India. Biol. Fertil. Soils, 14, 191-199.

30. Tripathi, S.K. \& Singh, K.P. (1994) Productivity and nutrient cycling in recently harvested and mature bamboo savannas in the dry tropics. J. Appl. Ecol., 31, 109-124.

31. Tripathi, S.K. \& Singh, K.P. (1996) Culm recruitment, dry matter dynamics and carbon flux in recently harvested and mature bamboo savannas in the Indian dry tropics. Ecol. Res., 11, 149-164.

32. Ugawa, S. et al. (2011) Characteristics of culm structure and carbon and nitrogen concentrations in dead bamboo culms of two Phyllostachys species. Plant Soil, 347, 269-278.

33. Yang, F.F. et al. (2010) Dynamics of coarse woody debris and decomposition rates in an old-growth forest in lower tropical China. For. Ecol. Manage., 259. 1666-1672.

34. Zebel, R.A. \& Morrell, J.J. (1992) Wood microbiology: decay and its prevention. Academic Press Inc., San Diego, USA, pp. 476 . 